\section{Cement kiln dust/rice husk ash as a low temperature route for wollastonite processing}

EmAD M. M. EWAIS - Refractory and Ceramic Materials Division(RCMD), Central Metallurgical R\&D Institute, Cairo • dr_ewais@hotmail.com

YASSER M. Z. AHMED - Refractory and Ceramic Materials Division(RCMD), Central Metallurgical R\&D Institute, Cairo

Ahmed A. M. EL-AMIR - Refractory and Ceramic Materials Division(RCMD), Central Metallurgical R\&D Institute, Cairo

HAMDY EL-DIDAMONY - Applied Inorganic Chemistry, Chemistry Dept., Faculty of Science, Zagazig University

Received: 25. 08. 2014. - Érkezett: 2014. 08. 25. " http://dx.doi.org/10.14382/epitoanyag-jsbcm.2014.14

\section{Abstract}

Eco-friendly and valuable commercial wollastonite based ceramics have been obtained from the most hazardous industrial and agrowastes (Cement kiln dust and rice husk ash) by reactive crystallization-sintering. Different batch compositions from cement kiln dust (CKD) with varying amounts of rice husk ash (RHA) were wet mixed, dried, grounded and sieved. Then, all batches were uniaxially pressed and fired at different temperatures $\left(1100-1200^{\circ} \mathrm{C}\right)$. Phase composition, microstructure, densification parameters, and mechanical properties of the obtained fired specimens were investigated. The results showed that wollastonite based ceramics were synthesized successfully at $1100^{\circ} \mathrm{C}$ without addition of any mineralizers. On the other hand, a considerable saving in time and heat energy were realized when an amorphous RHA silica was used instead of its other crystalline varieties. This was related to the higher reactivity of the amorphous RHA silica and its high specific surface area. The presented work made possible not only to overcome the environmental pollution ensuing from the accumulation of these industrial and agrowastes but also, to valorize and find added value to these residues. Conversion the latter into useful wollastonite-based ceramics with appropriate technology and environmental properties, allows the potential application in several fields. Hence, economic benefits will accrue to the producers and thus to the national economy.

Keywords: cement kiln dust (CKD), rice husk ash (RHA), batch composition, sintering, wollastonite, microstructure, phase composition, densification parameters, mechanical properties.

\section{Introduction}

While natural raw materials are becoming scarce and in some cases approach exhaustion, continuous industrial activity generates increasing quantities of wastes and by-products, of which disposal is subject to ever stricter environmental legislation [1]. The expansion in housing that relevant to world population growth in turn leads to the expansion in the cement industry. The total global cement production reached 3.7 billion tons in 2012 (according to the USGS mineral program report 2013) [2]. Depending on the alkalinity and the purity of the raw materials, about $0.17-10 \%$ of the produced clinker is bypass (CKD) [3]. This dust is generally grayish in color and consists predominately of silt-sized, non-plastic particles representing a mixture of partially calcined and unreacted raw feed, clinker dust and fuel ash enriched with alkali sulfates and halides and other volatiles [4]. Egypt produces annually about 48 million tons of clinker and according to the high alkalinity of Egyptian raw materials, the amount of CKD reaches $~ 10 \%$ of the clinker produced [3]. Thus, about 5 million tons of CKD is generated annually as a byproduct that can spread over a large area through wind and rain, becoming accumulated in plants, animals, and soils and consequently negatively affecting the environment and human health [5]. Many trials
Emad Mohamed M. Ewais earned his BSc in Chemistry (1987) as well as his MSc (1992) and PhD in Inorganic Chemistry (Ceramics) at the Faculty of Science, Cairo University, Egypt. He is a Professor and Head of the Refractory and Ceramic Materials Division (RCMD) of the Central Metallurgical R\&D Institute (CMRDI) in Cairo. He is also a member of the Institute of Materials, UK, and of other national Ceramic Societies. His wide-ranging research interests include the processing of ceramics, glass ceramics, refractory cement and castables and, especially, the properties and applications of advanced materials, wastes and refractories in metallurgical processes. Dr Ewais has authored and co-authored numerous international publications and has widely lectured on an international basis.

Yasser Momtaz Z. Ahmed earned his BSc in Chemistry (1989), his MSc 1994), and his PhD from the Faculty of Science, Ain Shams University, Cairo, Egypt. He is A Professor and Head of the advanced materials Department in the Central Metallurgical R\&D Institute (CMRDI) in Cairo. His research interests include the synthesis and characterization of nanostructured ceramic materials and synthesis, as well as the characterization of porous bodies of advanced materials suitable for various applications.

Ahmed A. M. El-Amir earned his BSc in Chemistry (1989) from the Faculty of Science, Zagazig University, Egypt. He is currently working as a research assistant at Refractory and Ceramic Materials Division in the Central Metallurgical R\&D Institute (CMRDI)

in Cairo.

Hamdy El-Didamony Ahmed earned his BSc in Chemistry (1963) and his MSC (1967) at the Faculty of Science, Cairo University, Egypt. He awarded his PhD (1973) from Witterberg University. He got his DSc (1999) from Zagazig University through Royal Society of England. His research interest include cement chemistry and building materials.

have been made for recycling CKD in various fields. However, the efforts that have been made to recycle/reuse the CKD are still very modest compared with the problem [6]. As a result, the accumulation of CKD in landfills became a progressively significant threat to the environment.

On the other hand, the worldwide production of rice paddy exceeded 730 million tons in 2012 (EG). This paddy consists of $72 \%$ rice, $5-8 \%$ of bran and $20-22 \%$ husk on average. Thus, 730 million tones of paddy will generate about 160 million tones of husk when grinding [7-9]. Husk, also called hulls, consists of the very hard outer shell covering the rice kernel to protect it during its growth [10]. It is the largest milling byproduct of the paddy. The husk contains about $75-85 \%$ organic volatile matter and ash around $15-25 \%$ by weight, depending on the plant variety, climatic conditions and geologic location [8-9]. In Egypt, during May 2012 to April 2013, it is reported that the production of rice paddy amounted to about 6.4 million tons that in turn gives 1.4 million tons of the husk when grinding. The husk in Egypt and most rice producing countries, is either dumped as waste, causing damage to the 
land and the surrounding area in which it is dumped or burnt for heat generation in ambient atmosphere leaving a residue, called RHA [7]. This ash is mostly silica (87-97\%) with small amounts of alkalies and other trace elements $[9,11]$. The silica therein is originally present in an active hydrated amorphous opaline state in the cellulose structure of rice husk [12]. Depending on time, rate and temperature of combustion and type of furnace/kiln used as well as the impurities present in the ash, the silica either remains in an amorphous phase or is transformed into its various crystalline polymorphs [1214]. Agrowastes (like RHA) are suitable materials for a wide range of industrial and research applications due to their low or zero cost, easy availability and their potential properties including higher active silica content, high porosity and low selfweight, very high specific surface area and extremely low thermal conductivity $[7,15]$. Recently, many efforts have been made to valorize the value of silicon rich rice husk ash and utilize it for the manufacture of a variety of useful products [7,9,12,14,16-26]. Despite having so many well established applications, little portion of rice husk produced is utilized in a meaningful way [10]. A large percentage of available husk is fired in boilers for raising steam for parboiling of paddy. Elsewhere it is piled up in heaps in open fields and periodically set on fire or simply dumped in nearby streams or used as cattle feeding.

Wollastonite $\left(\mathrm{CaSiO}_{3}\right)$ is a polymorphic substance and its three forms (woolastonite-1A, wollastonite-2M, and pseudowollastonite) can be found in nature [27]. Wollastonite has received much attention due to its potential properties such as acicular (needle-like) structure, high aspect ratio, high brightness and whiteness, low shrinkage, low loss on ignition (0.5-2\%), low moisture and oil absorption properties, lack of volatile constituents, high $\mathrm{pH}$, low thermal expansion, low thermal coefficient, non-toxicity, biocompatibility, and largely chemical inertness. It received wide range of applications in different fields such as traditional and advanced ceramics, automobile industry, metallurgy, paints, plastics and polymers.

Generally, natural wollastonite occurs in small amounts and is highly contaminated with other minerals such as diopside, calcite, dolomite, quartz, hedenbergite and granates [27]. Thus, in recent years, many efforts have been made to utilize different mineral resources along with most of industrial wastes for wollastonite synthesis by different methods [28-36]. Conversion CKD and RHA into useful wollastonite based ceramics with appropriate technology and environmental properties, allows their potential application in many industries. Economic benefits will accrue to the producers and thus to the national economy. Recently, Ewais et al prepared wollastonite and its composites successfully using CKD as calcia source and quartz sand as a silica source at $1150{ }^{\circ} \mathrm{C}$ (present research). This work targeted the replacement of quartz sand by the agrowastes (RHA) for economical and ecological demands. This work makes it possible not only to overcome the environmental pollution ensuing from the accumulation of these industrial and agrowastes, but also, to valorize and find value added to these residues.

\section{Materials and Experimental procedures}

\subsection{Starting materials}

The materials used in these investigations were (1) By-pass cement dust (CKD) provided by the national cement company, Helwan, Egypt. Representative samples of the dust were collected weekly for a period of 2 months and were blended to offer the raw dust. (2) Rice husk ash (RHA) produced by the uncontrolled combustion of RH (from the rice mills in Cairo, Egypt) in air using a laboratory-sintering machine at CMRDI in a manner similar to the production of energy using rice husk. Before designing the batches, mineral composition, chemical, thermal and particle size distribution analyses of these starting materials were made to specify the firing regime.

\subsection{Experimental procedures}

\subsubsection{Batch design}

Different batch compositions of CKD with 30-55 m\% RHA with an increment of $5 \mathrm{~m} \%$ were designed to prepare wollastonite and its composites (Table 1). The batches were assigned as $A_{30}, A_{35}, A_{40}, A_{45}, A_{50}, A_{55}$ where the index number indicates the mass percent of RHA in the batch composition and the rest represents the weight percent of CKD. To obtain homogeneous mixtures, these batches were mixed thoroughly with distilled water in planetary ball mill for 1 hour.

\begin{tabular}{lccccccc} 
Batch code & & $\mathbf{A}_{\mathbf{3 0}}$ & $\mathbf{A 3 5}$ & $\mathbf{A 4 0}$ & $\mathbf{A 4 5}$ & $\mathbf{A 5 0}$ & $\mathbf{A 5 5}$ \\
\hline $\begin{array}{l}\text { Raw materials } \\
(\mathbf{m} \%)\end{array}$ & $\mathrm{CKD}$ & 70 & 65 & 60 & 55 & 50 & 45 \\
\cline { 2 - 8 } & $\mathrm{RHA}$ & 30 & 35 & 40 & 45 & 50 & 55 \\
\hline C/S molar ratio & & 1.17 & 0.97 & 0.81 & 0.68 & 0.57 & 0.48
\end{tabular}

Table 1. Batch compositions

1. táblázat Keverék összetételek

The powder mixtures (dried at $100{ }^{\circ} \mathrm{C}$ for 24 hours in a controlled oven) were passed from standard screen of opening size of $36 \mu \mathrm{m}$, then were uniaxially die-pressed at $95 \mathrm{MPa}$ to form cylindrical shaped specimens. The obtained specimens were dried, then sintered at $1150^{\circ} \mathrm{C}, 1200^{\circ} \mathrm{C}$, and $1250^{\circ} \mathrm{C}$ for $2 \mathrm{hrs}$. The heating rate was $5^{\circ} \mathrm{C} / \mathrm{min}$. The mineral composition, densification parameters, microstructure, and mechanical properties of the obtained sintered specimens were investigated.

\subsubsection{Testing and characterization}

Particle size distribution and specific surface area of the starting materials were determined by a laser particle size analyzer Instrument (liquid mode) BT-2001 (China) and by an automated gas sorption system Quantachrome NOVA, (version 1.12, USA). In addition, chemical analyses of the starting materials were determined by Panalytical XRF (Model advanced Axios, Netherlands). Also, thermal analysis of the materials was carried out by TG-DSC NETZSCH STA 409 $\mathrm{C} / \mathrm{CD}$ through which samples were heated in air from room temperature up to $1400^{\circ} \mathrm{C}$ with a heating rate of $10^{\circ} \mathrm{C} / \mathrm{min}$ using $\alpha-\mathrm{Al}_{2} \mathrm{O}_{3}$ powder as standard reference. 
Mineral compositions of the raw materials and fired batches were identified by an X-ray diffractometer, model: Brukur advanced D8 Kristalloflex (Ni-filtered $\mathrm{Cu} \mathrm{K}_{\alpha}$ radiation; $\lambda=1.544 \AA$ ).

The microstructure of the fired and polished speciemens was examined by backscattered electron (BSE) in the field emission scanning electron microscopy (FESEM QUANTAFEG 250) connected to an energy dispersive X-ray microanalyzer (EDX).

Densification parameters in terms of apparent porosity and bulk density of sintered materials were determined by Archimedes immersion technique in ethanol by vacuum pressure according to ASTM C 830-00, 2000. The changes in linear shrinkage values of all specimens were calculated using a caliper by determining their diameters before and after sintering.

Mechanical properties in terms of compressive strength and microhardness were determined. The compressive strength of the fired specimens was determined at a rate of $1.3 \mathrm{~mm} /$ min by universal testing machine (Shimadzu, UH-F $1000 \mathrm{KN}$, Japan). Microhardness of the obtained specimens have been determined at room temperature, on the polished surface considering an average of five indentations for each specimen by using Vickers indentation method to load of $100 \mathrm{~g}$ for $15 \mathrm{~s}$ by Vickers microhardness testing machine (TTSUNLIMITED, HWDM-7, Japan). Vickers hardness was computed by Eq. (1):

$\mathrm{Hv}=0.0018544\left(\mathrm{p} / \mathrm{d}^{2}\right)$

Where $\mathrm{p}$ is the indentation load $(\mathrm{N}), \mathrm{d}$ is the average length of the two diagonals of the indentation $(\mathrm{mm})$. Hv is the Vickers hardness in units of $(\mathrm{GPa})$.

\section{Results and discussion}

\subsection{Starting raw materials}

Both particle size distribution and specific surface area of the raw materials are given in Table 2 while Table 3 shows the chemical composition of both CKD and RHA. XRF of RHA indicates that it consists mainly of $\mathrm{SiO}_{2}(79.84 \%)$ and $\mathrm{K}_{2} \mathrm{O}(5.09 \%)$ with small amounts of impurities in the form of calcium, aluminum, magnesium, sodium, and iron oxides along with $1.16 \% \mathrm{SO}_{3}$ and $1.63 \% \mathrm{Cl}$. The XRD pattern of $\mathrm{RHA}$ revealed that; no peaks can be observed except those for sylvite (KCl, JCPDS\# 73-0380) at d-spaces 3.14 and 2.22 Fig. 1a. The halo at $2 \theta=15-35^{\circ}$ is peculiar XRD characteristic of amorphous $\mathrm{SiO}_{2}$ with silanol ( $\left.\mathrm{Si}-\mathrm{OH}\right)$ groups [37]. Regarding the thermal behavior, TG and DSC curves (Fig. 2a) Show an endothermal event centered around $90^{\circ} \mathrm{C}$ due to the removal of physically bound water (i.e. moisture) in the ash. In particular the weight loss associated with this reaction is about $4 \mathrm{~m} \%$.

The major mass loss of $\sim 20 \%$, exhibited over the temperature range of $283^{\circ} \mathrm{C}$ and $600{ }^{\circ} \mathrm{C}$, is attributed to the release of organic volatile matters and burning of combustible material (fixed carbon) present in the ash. The volatiles in the presence of oxygen undergo flamed combustion giving rise to the broad exothermic peak in DSC centered around $450{ }^{\circ} \mathrm{C}$. The inappreciable gradual weight loss that is observed above $600{ }^{\circ} \mathrm{C}$
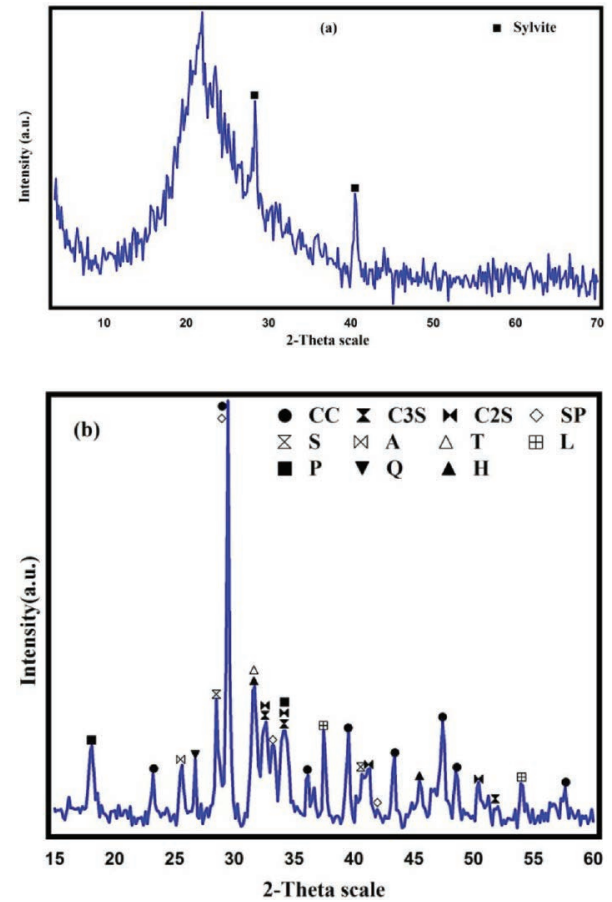

Fig. 1. XRD patterns of (a) rice husk ash RHA and (b) cement kiln dust CKD

1. ábra Röntgendiffraktogramok (a) rizshéj hamu, RHA (b) cement kemencehamu, CKD
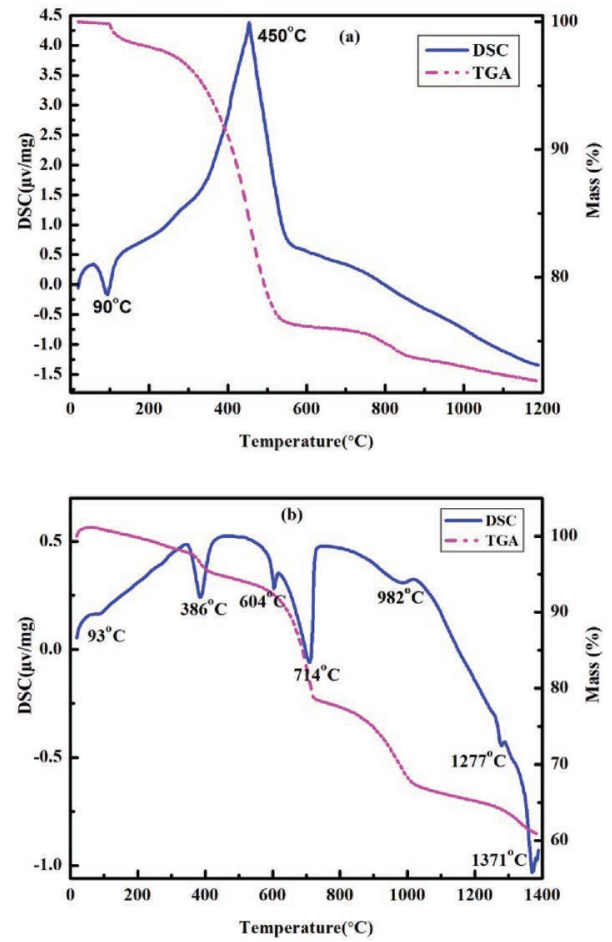

Fig. 2. TG-DSC curves of (a) rice husk ash RHA and (b) cement kiln dust CKD

2. ábra Termogravimetriai vizsgálatok eredményei (a) rizshéj hamu, RHA (b) cement kemencehamu, CKD

\begin{tabular}{lcccc} 
Raw materials & $\mathbf{D}_{10}, \mu \mathrm{m}$ & $\mathbf{D}_{50}, \boldsymbol{\mu m}$ & $\mathbf{D}_{90}, \mu \mathrm{m}$ & $\begin{array}{c}\text { Specific surface } \\
\text { area, } \mathbf{~ m}^{2} / \mathrm{g}\end{array}$ \\
\hline Cement kiln dust & 2.419 & 12.84 & 42.64 & $4.541 \mathrm{E}+01$ \\
\hline Rice husk ash & 9.693 & 38.75 & 82.21 & $1.171 \mathrm{E}+02$
\end{tabular}

Table 2. Particle size distribution and surface area of the raw materials. 2. táblázat Kiindulási anyagok szemcseméret-eloszlása és fajlagos felülete 


$\begin{array}{lccccccccccccc}\text { Oxide raw material } & \mathrm{Na}_{2} \mathbf{O} & \mathbf{M g O} & \mathbf{A l}_{2} \mathbf{O}_{3} & \mathbf{S i O}_{2} & \mathbf{P}_{\mathbf{2}} \mathbf{O}_{\mathbf{5}} & \mathbf{S O}_{3} & \mathbf{K}_{\mathbf{2}} \mathbf{O} & \mathbf{C a O} & \mathrm{TiO}_{2} & \mathbf{F e}_{2} \mathbf{O}_{3} & \mathbf{F} & \mathbf{C l} & \mathbf{L} . \mathbf{0 . I} \\ \text { Cement kiln dust } & 3.52 & 1.33 & 2.17 & 7.58 & 0.12 & 4.45 & 3.31 & 45.06 & 0.26 & 2.62 & 0.11 & 6.52 & 22.95 \\ \text { Rice husk ash } & 0.50 & 0.75 & 0.60 & 79.84 & 1.58 & 1.16 & 5.09 & 1.34 & - & 0.33 & - & 1.63 & 7.18\end{array}$

Table 3. Chemical analyses of the raw materials

3. táblázat Kiindulási anyagok kémiai összetétele

in the TG is ascribed to the further oxidation of carbon in the residual intermediate to form other volatile species. Also, due to the moisture release during conversion of silanol $(\mathrm{Si}-\mathrm{OH})$ group into siloxane ( $\mathrm{Si}-\mathrm{O}-\mathrm{Si}$ ) group in cristobalite [7]. The DSC records exhibit an exothermic reaction during the course of thermal decomposition and an endothermic peak during the removal of moisture.

CKD is a potential source of oxides. XRF of CKD showed that $\mathrm{CaO}(45.06 \%)$ is the most abundant component. Also, it contains a significant quantity of $\mathrm{SiO}_{2}$ (7.58\%) as well as other oxides such as $\mathrm{Na}_{2} \mathrm{O}, \mathrm{MgO}, \mathrm{Al}_{2} \mathrm{O}_{3}, \mathrm{SO}_{3}, \mathrm{~K}_{2} \mathrm{O}$ and $\mathrm{Fe}_{2} \mathrm{O}_{3}$ that could act as mineralizers and fluxes during firing of the batch compositions. XRD pattern of CKD shown in Fig. 1a, revealed that this dust is a very complex material consisted of more than eleven compounds. These compounds are calcite (CaCO3: JCPDS\# 01-089-2340), hatrurite ( $\mathrm{Ca}_{3} \mathrm{SiO}_{5}$ : JCPDS\# 016-0407), portlandite ( $\mathrm{Ca}(\mathrm{OH})_{2}$ : JCPDS\# 01-070-5492), burnt lime (CaO: JCPDS\# 004-0777), anhydrite $\left(\mathrm{CaSO}_{4}\right.$ :JCPDS\# 01-072-0916), sylvite (KCl: JCPDS\# 001-0786) and quartz ( $\mathrm{SiO}_{2}$ : JCPDS\# 005-0490), larnite $\left(\mathrm{Ca}_{2} \mathrm{SiO}_{4}\right.$ : JCPDS\# $083-$ 0461), halite ( $\mathrm{NaCl}$ : JCPDS\# 005-0628), spurrite $\left(2\left(\mathrm{Ca}_{2} \mathrm{SiO}_{4}\right)\right.$. $\mathrm{CaCO}_{3}$ : JCPDS\# 004-0640) and ternesite $\left(2\left(\mathrm{Ca}_{2} \mathrm{SiO}_{4}\right) \cdot \mathrm{CaSO}_{4}\right.$ : JCPDS\# 088-0812). The actual mechanism for formation of alkali chlorides, $\mathrm{CaSO}_{4}$, spurrite and sulphospurrite in the kiln is complicated; however, the following reactions and events are possible. During the clinker manufacture, the alkalis are liberated from the clay mineral lattice. They partly dissociate into the gas phase and recombine directly with chlorine or sulfur present in the charge material according to the affinities order [38]. Firstly, the chlorides are liberated during heating of the material and combustion of the fuel, combine with the alkalis forming $\mathrm{KCl}$ and $\mathrm{NaCl}$ [38]. Sometimes, chlorides are introduced as $\mathrm{NaCl}$ or $\mathrm{KCl}$ from sea water [38]. According to the priority, the remaining alkalis should react with the produced $\mathrm{SO}_{3}$ from the oxidation of sulfur in the raw materials and the fuels burned in the kiln, forming $\mathrm{Alk}_{2} \mathrm{SO}_{4}$. However, in this case all alkalis react with the chlorides. Thus, the formed $\mathrm{SO}_{3}$ reacts with lime or $\mathrm{CaCO}_{3}$ forming $\mathrm{CaSO}_{4}$ [39-40], Eq. (2). In clinkering zone, beyond $1300^{\circ} \mathrm{C}$, the formed $\mathrm{CaSO}_{4}$ melts and re-decomposes giving $\mathrm{SO}_{2}$ [40], Eq. (3). The formed elements $\left(\mathrm{NaCl}, \mathrm{KCl}, \mathrm{SO}_{2}\right)$ volatilize in the hot zones of the kiln and condensate at the colder areas [38]. These circulating elements form eutectic melts, which have much lower melting temperatures than the single compounds $>) 700^{\circ} \mathrm{C}$ ) [38]. All these melts, when present in sufficient quantity, generate severe encrustations and build-up formation in the preheater and the kiln inlet area [38]. These deposit buildups can lead to blocks that need to be removed, sometimes by a temporary plant shutdown [40]. Spurrite and sulphospurrite are the principal constituents of deposit buildups found in rotary kilns and kiln riser ducts. Spurrite is intensively formed in a small range of temperatures $\left(885-912^{\circ} \mathrm{C}\right)$, due to the accumulation of eutectic chloride melts, either: (1) by direct reaction of $\mathrm{CaCO}_{3}$ and silica, or (2) by the reaction of $\mathrm{CaO}, \mathrm{Ca}_{2} \mathrm{SiO}_{4}$ and gaseous $\mathrm{CO}_{2}$ [41]. In addition, Increasing amounts of circulating $\mathrm{SO}_{2}$ in the cement kiln system, promotes the formation of sulphospurrite $\left(2 \mathrm{C}_{2} \mathrm{~S}\right.$. $\left.\mathrm{CaSO}_{4}\right)$ at the same temperature range for spurrite formation [40].

$$
\begin{aligned}
& \mathrm{CaO}+\mathrm{SO}_{2}+0.5 \mathrm{O}_{2} \stackrel{500-1000^{\circ} \mathrm{C}}{\longrightarrow} \mathrm{CaSO}_{4} \\
& \mathrm{CaSO}_{4} \stackrel{1280-1300^{\circ} \mathrm{C}}{\longrightarrow} \mathrm{CaO}+\mathrm{SO}_{2}+0.5 \mathrm{O}_{2}
\end{aligned}
$$

As can be seen from TG-DSC curves of CKD (Fig. 2), the weight loss variations over the heating range from the room temperature up to $1400{ }^{\circ} \mathrm{C}$ was $40.05 \%$. These variations were accompanied by endothermic peaks at different temperature ranges in the following sequence; $93^{\circ} \mathrm{C}, 386^{\circ} \mathrm{C}, 604^{\circ} \mathrm{C}, 714^{\circ} \mathrm{C}$,

\begin{tabular}{|c|c|c|c|c|}
\hline $\begin{array}{l}\text { Temperature } \\
\text { range }\left({ }^{\circ} \mathrm{C}\right)\end{array}$ & Process & $\begin{array}{l}\text { Thermal } \\
\text { change }\end{array}$ & Chemical transformation & Weight loss \\
\hline $25-310$ & $\begin{array}{l}\text { Evaporation of free and } \\
\text { physically adsorbed water }\end{array}$ & Endothermic & $\mathrm{H}_{2} \mathrm{O}_{(\mathrm{l})} \longrightarrow \mathrm{H}_{2} \mathrm{O}_{(\mathrm{g})}$ & $3.22 \%$ \\
\hline $310-500$ & Dehydroxylation of portlandite & Endothermic & $\mathrm{Ca}(\mathrm{OH})_{2} \longrightarrow \mathrm{CaO}+\mathrm{H}_{2} \mathrm{O}$ & $4.25 \%$ \\
\hline $500-764$ & Decomposition of $\mathrm{CaCO}_{3}$ & Endothermic & $\mathrm{CaCO}_{3} \longrightarrow \mathrm{CaO}+\mathrm{CO}_{2}$ & $15.24 \%$ \\
\hline $764-1200$ & $\begin{array}{c}\text { Dissociation of spurrite and } \\
\text { sublimation of alkaline chlorides }\end{array}$ & Endothermic & 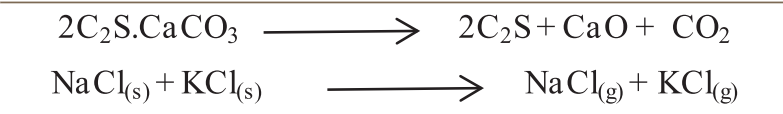 & $12.87 \%$ \\
\hline $1200-1380$ & $\begin{array}{l}\text { Decomposition of both anhydrite } \\
\text { and sulphospurrite }\end{array}$ & Endothermic & $\begin{aligned} \mathrm{CaSO}_{4} & \longrightarrow \mathrm{CaO}+\mathrm{SO}_{2}+0.5 \mathrm{O}_{2} \\
2 \mathrm{C}_{2} \mathrm{~S}_{\mathrm{CaSO}} & \longrightarrow 2 \mathrm{C}_{2} \mathrm{~S}+\mathrm{CaO}+\mathrm{SO}_{2}+0.5 \mathrm{O}_{2}\end{aligned}$ & $4.47 \%$ \\
\hline
\end{tabular}
$982^{\circ} \mathrm{C}, 1277^{\circ} \mathrm{C}$, and $1371^{\circ} \mathrm{C}$. The first mass loss recorded 
(3.22\%) from ambient temperature to approximately $310^{\circ} \mathrm{C}$ was due to the evaporation of free and physically adsorbed water as indicated by the endothermic peak centered around $93^{\circ} \mathrm{C}$ in DSC curve. The second mass loss (4.25\%) from $310^{\circ} \mathrm{C}$ up to approximately $500^{\circ} \mathrm{C}$, can be attributed to the dehydroxylation of portlandite $\left(\mathrm{Ca}(\mathrm{OH})_{2}\right)$ [42]. This loss is accompanied by an endothermic peak centered around $386^{\circ} \mathrm{C}$ in DSC curve. The further mass loss (15.24\%) recorded over the temperature range of $500^{\circ} \mathrm{C}$ to $764^{\circ} \mathrm{C}$ was accompanied by two endothermic peaks at $\sim 604^{\circ} \mathrm{C}$ and $\sim 714^{\circ} \mathrm{C}$. The first endothermic peak is due to the loss of $\mathrm{CO}_{2}$ during decomposition of amorphous $\mathrm{CaCO}_{3}$ or carbonates with finer crystalline structure and the second is attributed to the loss of $\mathrm{CO}_{2}$ during decomposition of more crystalline $\mathrm{CaCO}_{3}$ [42-43]. Moreover, the weight loss $(12.87 \%)$ recorded in the temperature range (764 to $1200^{\circ} \mathrm{C}$ ) is ascribed to the dissociation of spurrite phase and sublimation of alkaline chlorides from a raw mixture. This loss is accompanied by a broad endothermic peak centered at $982^{\circ} \mathrm{C}$ in DSC curve. This is compatible with published data; (1) Dissociation of spurrite occurs at a higher temperature than the $\mathrm{CaCO}_{3}$ itself, inasmuch as the greater thermal stability of spurrite than $\mathrm{CaCO}_{3}$ due to the substitution of the dissociable groups into the stable lattice in spurrite [39]. (2) The sublimation of alkaline chlorides begins after the thermal decomposition of calcium carbonate and finishes at $1200^{\circ} \mathrm{C}$ [44-45]. With regard to the endothermic peak recorded around $1277^{\circ} \mathrm{C}$, it may be ascribed to the decomposition of both anhydrite $\left(\mathrm{CaSO}_{4}\right)[38,40]$ and sulphospurrite phase [39]. The latter two decompositions are accompanied by a mass loss of $4.47 \%$ in the temperature range $\left(1200^{\circ} \mathrm{C}\right.$ to $\left.1380^{\circ} \mathrm{C}\right)$ [46]. As for the last endothermic peak centered at $1371^{\circ} \mathrm{C}$ in the DSC curve, it is attributed to the partial melting of the sample [47]. All thermal events occurring during thermal treatment of CKD is summarized in Table 4.

\subsection{Phase composition of the fired batches}

Figs. 3, 4 and 5 show the powder XRD patterns of the fired specimens $A_{30}$ to $A_{55}$ in the temperature range $1100{ }^{\circ} \mathrm{C}$ to $1200^{\circ} \mathrm{C}$ with $50{ }^{\circ} \mathrm{C}$ intervals. The results showed that, the crystalline phases present in these fired specimens are wollastonite-2M, cyclowollastonite, cristobalite and akermanite. At $1100{ }^{\circ} \mathrm{C}$, the specimen $\mathrm{A}_{30}$ was found to contain wollastonite- $2 \mathrm{M}$ with minor amounts of akermanite phase. On the further addition of RHA up to $40 \mathrm{~m} \%$ in the compositions, wollastonite- $2 \mathrm{M}$ was recorded without any other phases. Then, cristobalite appeared along with wollastonite-2M, upon addition of $<40 \mathrm{~m} \%$ RHA in the compositions. At $1150{ }^{\circ} \mathrm{C}$, the same situation was recorded except that the cristobalite phase is detected only in $\mathrm{A}_{55}$ rather than its detection in $A_{45}, A_{50}$ and $A_{55}$ specimens at $1200{ }^{\circ} \mathrm{C}$. At $1200^{\circ} \mathrm{C}$, the specimen $\mathrm{A}_{30}$ was found to contain mainly the high temperature polymorph (cyclowollastonite) along with minor amounts of akermanite phase. However, in the remaining specimens $\mathrm{A}_{35}-\mathrm{A}_{55}$, the low temperature polymorph (wollastonite-2M) was detected as a sole phase except for the specimens $A_{35}$ and $A_{55}$. Minor amounts of other phases were detected in these two specimens, cyclowollastonite in $\mathrm{A}_{35}$ and cristobalite in $\mathrm{A}_{55}$, along with the major wollastonite-2M phase. The results obtained from the XRD patterns are summarized in

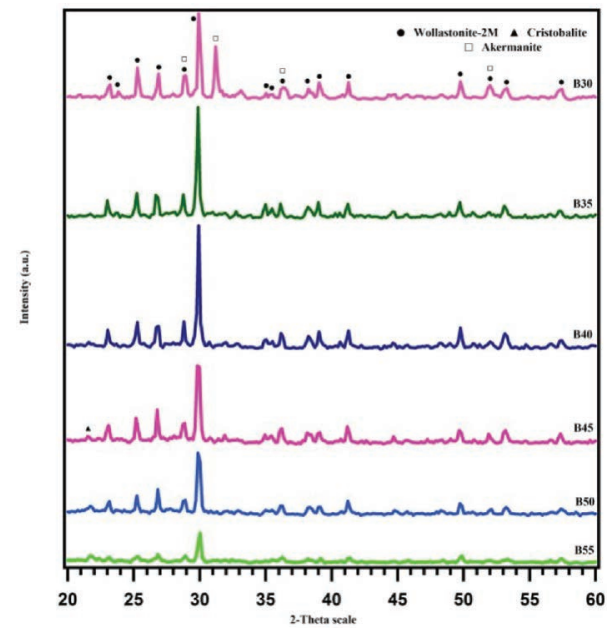

Fig. 3. XRD patterns for all composition batches sintered for $2 \mathrm{hrs}$ at $1100^{\circ} \mathrm{C}$

3. ábra A 2 órán át, $1100^{\circ} \mathrm{C}$ hömérsékleten szinterelt keverékek röntgendiffraktogramjai

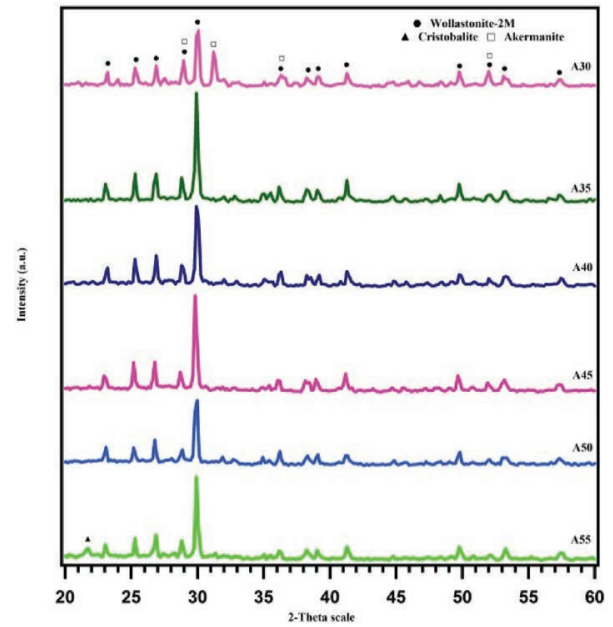

Fig. 4. XRD patterns for all composition batches sintered for 2 hrs at $1150^{\circ} \mathrm{C}$

4. ábra A 2 órán át, $1150^{\circ} \mathrm{C}$ hömérsékleten szinterelt keverékek röntgendiffraktogramjai

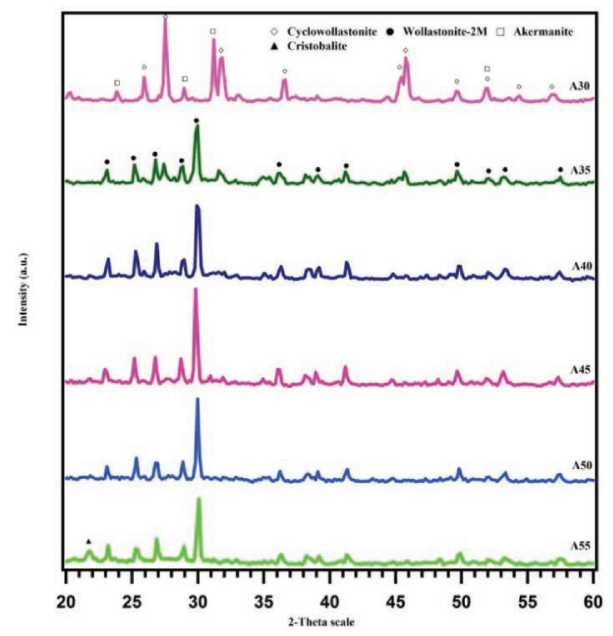

Fig. 5. XRD patterns for all composition batches sintered for 2 hrs at $1200^{\circ} \mathrm{C}$

5. ábra A 2 órán át, $1200^{\circ} \mathrm{C}$ hömérsékleten szinterelt keverékek röntgendiffraktogramjai 


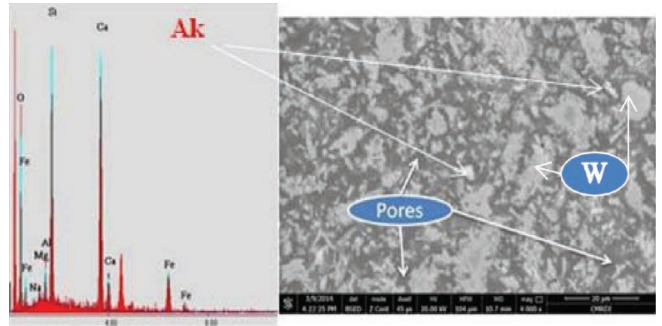

$A_{30}$
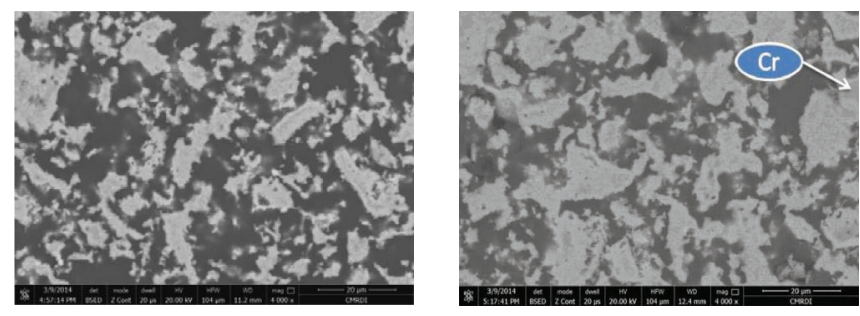

$A_{35}$

$A_{40}$

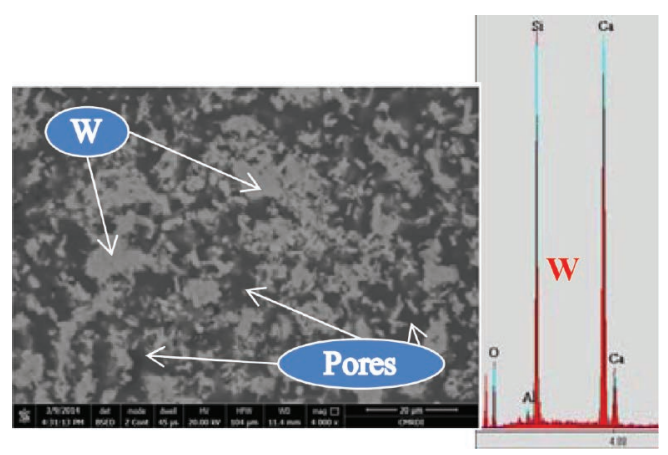

$A_{45}$

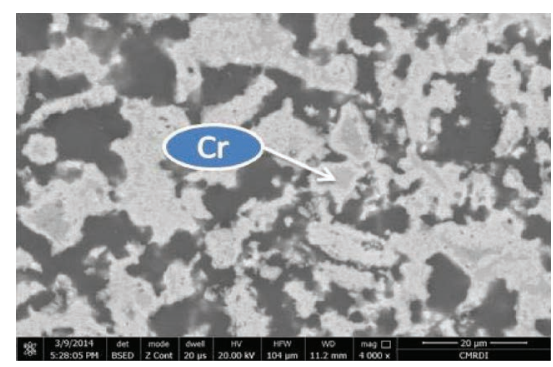

$A_{50}$

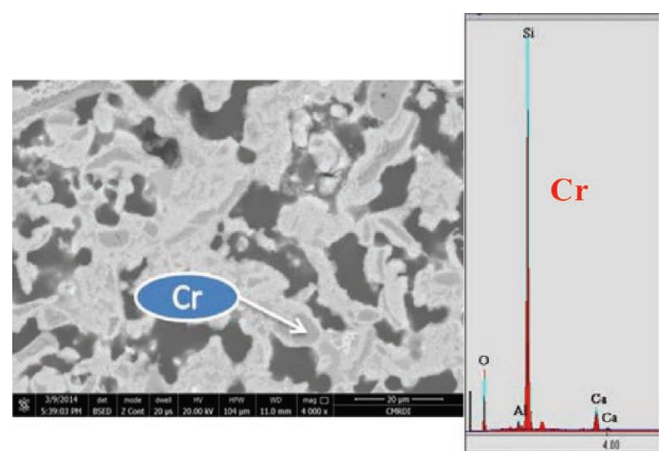

$A_{55}$

Fig. 6. Microstructure of all batches sintered for $2 \mathrm{hrs}$ at $1100^{\circ} \mathrm{C}$, Cr: cristobalite, Ak: akermanite, W: wollastonite.

6. ábra A 2 órán át, $1100^{\circ} \mathrm{Chőmérsékleten} \mathrm{szinterelt} \mathrm{keverékek} \mathrm{mikroszerkezete;}$ Cr: krisztobalit, Ak: akermanit, W: wollastonit
Table 5. There are some phenomena could be deduced from the XRD patterns. The first phenomenon is the separation of the cristobalite phase in specimens containing high RHA content, whatever is the temperature. This is logic where at higher RHA addition, the excess stoichiometrically amount of RHAS is supposed to be dissolved in the liquid saturating it in silica. Thereafter, the remaining RHAS after complete saturation of liquid in silica was crystallized into cristobalite. From the above findings, it is clear that the transformation sequence of RHAS supports the view of Flörke [48]. According to Flörke, the silica can be transformed into cristobalite without the intermediate stage of tridymite depending on the degree of purity of starting materials. In addition, the presence of tridymite is governed by the kind and amount of impurities. The second phenomenon is the appearance of the high temperature polymorph phase (cyclowollastonite) only in the specimens sintered at $1200^{\circ} \mathrm{C}$ $\left(\mathrm{A}_{30}\right.$ and $\left.\mathrm{A}_{35}\right)$. This can be explained in terms of the following two factors: (1) The higher alkali content $(70 \mathrm{~m} \%$ and $65 \mathrm{~m} \%)$ and the lower quartz content $(30 \mathrm{~m} \%$ and $35 \mathrm{~m} \%$ ) found in these two specimens, compared to other specimens. (2) The high temperature $\left(1200^{\circ} \mathrm{C}\right)$. It is well known that silica is a network former that group to form $\left(\mathrm{SiO}_{4}\right)^{4-}$ tetrahedra. These complex ions $\left(\mathrm{SiO}_{4}\right)^{4-}$ join together at their vertices forming three dimensional hexagonal networks leading to increasing the viscosity of the liquid phase formed during firing. On the other hand, basic and alkaline basic oxides like $\mathrm{CaO}, \mathrm{MgO}$, $\mathrm{Fe}_{2} \mathrm{O}_{3}, \mathrm{Na}_{2} \mathrm{O}$ and $\mathrm{K}_{2} \mathrm{O}$ present in $\mathrm{CKD}$ are called network breakers since they can dissociate giving oxygen ions $\left(\mathrm{O}^{2-}\right)$ that can react with the hexagonal network of silica and destroy it. Hence, addition of basic oxides decreases the viscosity of the silica liquid phase by breaking its hexagonal network [49-50]. Also, it is well known that the viscosity of the liquid phase formed during firing decreases largely with the increase of firing temperature. Based on the aforementioned, the higher the alkali oxide content and the lower the silica content in these two specimens at higher temperature $\left(1200^{\circ} \mathrm{C}\right)$, the lower the viscosity of the liquid phase formed during firing of these two specimens. The existence of liquid phase of lower viscosity during firing, enhances the reaction kinetics and increases the chemical communication between the reacting phases [51]. This accelerates the diffusion of all the coexisting ions leading on heating and/or cooling to cyclowollastonite crystallization. In addition, the increase of silica content for $\mathrm{A}_{40}-\mathrm{A}_{55}$ specimens at the expense of CKD leads to the decrease of the alkali amount in the compositions and this in turns leads to the increase of the viscosity of the liquid phase which hinders the diffusion of the coexisting ions during heating and/or cooling. As a result, cyclowollastonite crystallization is prevented. Therefore, the key factor that controls the formation of the cyclowollastonite is the viscosity of the formed liquid that depends on both temperature and mount of alkalis in CKD. Thus, at $1200^{\circ} \mathrm{C}$, the appearance of cyclowollastonite at lower silica content specimen $A_{30}$ is very easy from the presence of high alkali amount and the high temperature of firing. The third phenomenon is the appearance of akermanite phase only in the specimen $A_{30}$ whatever the firing temperature. In nature, akermanite occurs up to $1300^{\circ} \mathrm{C}$ in the silica-undersaturated igneous rocks. Claude et al [52] also showed that, when a mixture of chalk and 
silica is fired at $1150^{\circ} \mathrm{C}$, pseudowollastonite is formed together with approximately $15 \%$ by weight akermanite relative to the total product obtained, depending on the impurities present. In addition, ElBatal et al [53] detected previously akermanite in the fired mixture of slag and CKD. Based on this, the accompaniment of wollastonite by akermanite phase in the fired CKD-Qtz mixtures at $\left(1100^{\circ} \mathrm{C}\right.$ to $\left.1200^{\circ} \mathrm{C}\right)$, is logic. With regard to, the appearance of akermanite only in the specimen $\mathrm{A}_{30}$ and the disappearance of its X-Ray lines completely from the specimen $A_{35}$, upon addition of $5 \mathrm{~m} \%$ silica at the expense of the dust can be explained in terms of the ratio $(\mathrm{Na}+\mathrm{K}+\mathrm{Mg}+\mathrm{Ca} / \mathrm{Al}+\mathrm{Si})$ (Table 1). Akermanite (one member of the melilite group) is a loosely-defined mineral deficient in silica [54]. It crystallizes from silica and alumina poor, alkalirich compositions at $700{ }^{\circ} \mathrm{C}[55]$. Among the elements (Na, $\mathrm{K}, \mathrm{Ca}, \mathrm{Mg}$ ), $\mathrm{Na}$ is the most important element, if not the sole influence on akermanite crystallization [55]. According to $(\mathrm{Na}+\mathrm{K}+\mathrm{Mg}+\mathrm{Ca} / \mathrm{Al}+\mathrm{Si})$ ratio, the specimen $\mathrm{A}_{30}$ is depleted in silica and alkali-rich while in contrast the specimens $A_{35}-A_{55}$ are silica-rich and alkali-poor. Therefore, akermanite is formed in $A_{30}$ due to the silica deficiency and alkali-richness of this specimen. Furthermore, the disappearance of the X-ray lines for akermanite, in the specimen $\mathrm{A}_{35}$ is accompanied by the increase of wollastonite. This suggests that, in the presence of excessive silica in oxidative conditions, wollastonite may form at the expense of metastable phase akermanite by its reaction with the excessive silica at higher silica content specimens through the following reversible reaction $[41,56]$ :

melilite + silica + oxygen

$\longrightarrow$ wollastonite + amorphous substances

This assumption is supported by the increase of the amount of glassy phase, which can be seen in FE-SEM Figs. 6, 7 and 8. Also, the drastic increase of shrinkage (Fig. 9) observed in the temperature range $1100-1200^{\circ} \mathrm{C}$ reveal the progressive formation of a melt. This is not unexpected, since the starting material (CKD) is rich in fluxing agents [57].

\subsection{Microstructure of the fired batches}

The backscattered FE-SEM photomicrographs of the polished surfaces of all specimens containing various $\mathrm{CKD}$ and $\mathrm{RHA}$ compositions and fired at $1100^{\circ} \mathrm{C}, 1150{ }^{\circ} \mathrm{C}$ and $1200^{\circ} \mathrm{C}$, were shown in Figs. 6, 7 and 8, respectively. The general overview for all micrographs confirms the large reduction in both pore size and total porosity with the increase of firing temperature and RHA content, this is congruent with the densification behavior (section 3.4). This can be explained in terms of the enhancing in sinterability that results from the formation of more liquid phase with the increase of the two factors $[13,58]$. The enhancement in liquid facilitates the grain boundaries to contact on the expense of the entire porosity leading to pore closing and elimination. After complete vitrification of the specimen $\mathrm{A}_{50}\left(\right.$ at $\left.1150^{\circ} \mathrm{C}\right)$ and $\mathrm{A}_{45}\left(1200^{\circ} \mathrm{C}\right)$, the higher addition of RHA to these vitrified specimens led to the formation of large pores in the subsequent specimens $A_{55}$ (at $1150^{\circ} \mathrm{C}$ ) and $A_{50}$ to $A_{55}\left(1200^{\circ} \mathrm{C}\right)$. The reappearance of pores in such specimens can be attributed to the increase of silica content

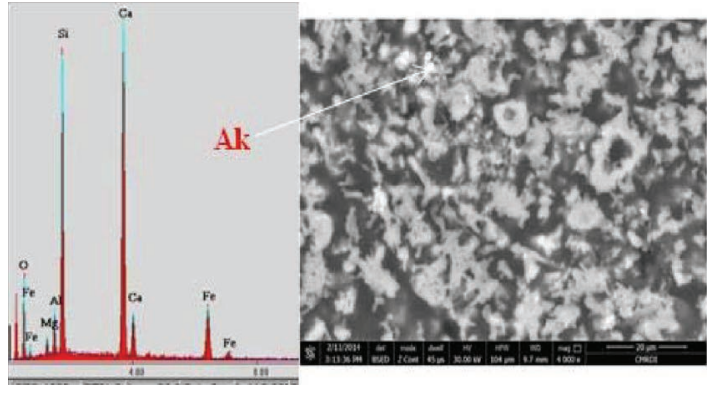

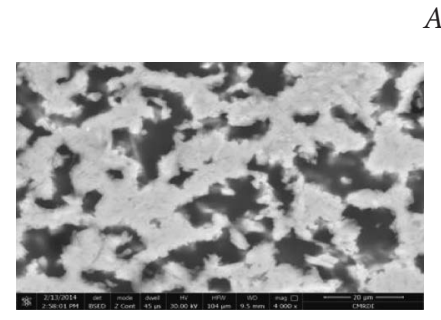

$A_{35}$

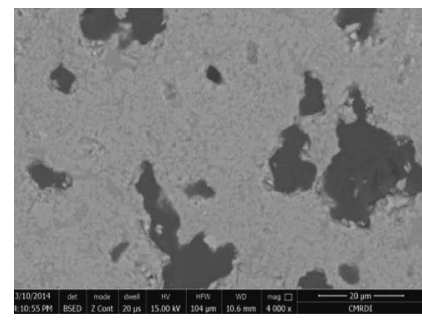

$A_{45}$
$A_{30}$

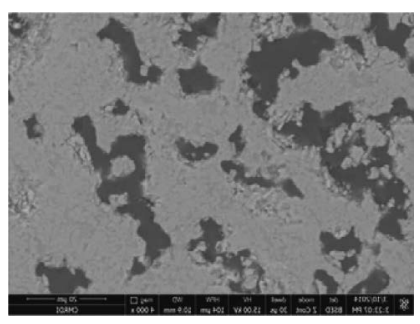

$A_{40}$

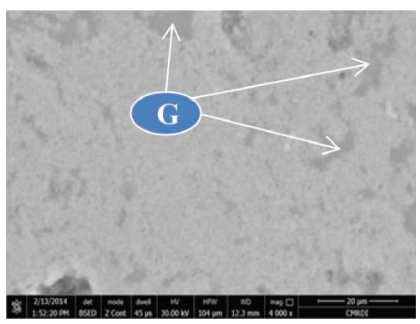

$A_{50}$

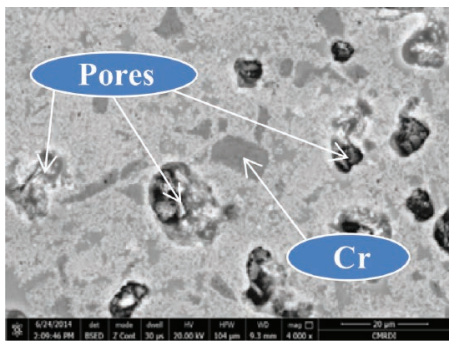

$A_{55}$

Fig. 7. Microstructure of all batches sintered for $2 \mathrm{hrs}$ at $1150^{\circ} \mathrm{C}$, Ak: akermanite, Cr: cristobalite, G: glass.

7. ábra A 2 órán át, $1150^{\circ} \mathrm{C}$ hömérsékleten szinterelt keverékek mikroszerkezete; Cr: krisztobalit, Ak: akermanit, G: üveg

in these specimens that leads to: (1) increasing the viscosity and blocking the viscous flow by formation of silica clusters through the interlocking of $\mathrm{SiO}_{4}$ tetrahedra [50], assuming that they pack together in an irregular way giving increasingly porous microstructure. The increase of the concentration of these clusters in the glass increases with $\mathrm{SiO}_{2}$ content. (2) The formation of more glassy phase through which some gases can migrate into the matrix creating closed pores and bloating the specimen. Not only the pore size and total porosity are highly affected by increasing both temperature and RHA amounts, but also the pore shape is highly influenced by increasing both the two factors. As shown in micrographs, the shape of the voids in the fired specimens takes one of the following three shapes: (1) Voids are highly connected to each other, forming 
a grid like cobweb, displayed by all specimens fired at $1100^{\circ} \mathrm{C}$ and specimens $\mathrm{A}_{30}$ and $\mathrm{A}_{35}$ fired at $1150^{\circ} \mathrm{C}$. Such pores are difficult to be described in terms of their size and shape. (2) Irregular and highly distributed voids, having large size ranges from 2 to $40 \mu \mathrm{m}$, displayed by the fired specimens $\mathrm{A}_{40}, \mathrm{~A}_{45}$ and $A_{55}\left(\right.$ at $1150^{\circ} \mathrm{C}$ ) and $A_{30}, A_{35}, A_{50}$ and $A_{55}$ (at $1200^{\circ} \mathrm{C}$ ). (3) Small irregular pores, having size ranges from 0.1 to $6 \mu \mathrm{m}$, displayed by some of the following surface vitrified fired specimens $\mathrm{A}_{50}$ (at $1150^{\circ} \mathrm{C}$ ) and $\mathrm{A}_{40}$ and $\mathrm{A}_{45}\left(\right.$ at $1200^{\circ} \mathrm{C}$ ). With regard to the size and shape of the formed crystals, the SEM-EDX results showed that the fired specimens at $1100^{\circ} \mathrm{C}$ and $1150{ }^{\circ} \mathrm{C}$ displayed a sparse granules of wollastonite- $2 \mathrm{M}$ of a size $0.5-12 \mu \mathrm{m}$, imbedded in glassy phase and distributed in a highly porous texture that is similar to the structure of bacterial colonies in a nutrient medium. The fired specimens at $1200{ }^{\circ} \mathrm{C}$, displayed a compact flat surface of wollastonite crystals, embedded in a glassy matrix. Minor amounts of bright grains were observed along with the wollastonite in the specimen $\mathrm{A}_{30}$ through the investigated temperature range $\left(1100-1200^{\circ} \mathrm{C}\right)$. EDX of these bright spots in Figs. 6, 7 and 8 showed that they consist mainly of $\mathrm{Ca}, \mathrm{Si}$ with smaller amounts of $\mathrm{Mg}, \mathrm{Al}$, and Fe. The presence of $\mathrm{Ca}, \mathrm{Si}$ as major peaks and a lesser amount of $\mathrm{Mg}$ suggests the presence of akermanite. These results confirm the result obtained from XRD [59]. Also, cristobalite grains sub-rounded by worm-like wollastonite- $2 \mathrm{M}$ were seen in the fired specimens $\mathrm{A}_{45}, \mathrm{~A}_{50}$ and $\mathrm{A}_{55}$ (at $1100^{\circ} \mathrm{C}$ ), and $\mathrm{A}_{55}$ (at $1150^{\circ} \mathrm{C}$ and $1200^{\circ} \mathrm{C}$ ). Hence, it is evident that in all the micrographs, the major phase present was the wollastonite, apart from other minor amounts of akermanite, cristobalite and glassy phases.

\subsection{Densification parameters}

Densification parameters - in terms of diagonal shrinkage, bulk density, and apparent porosity - of all specimens having various compositions $A_{30}-A_{55}$ have been investigated as a function of temperature $\left(1100-1200^{\circ} \mathrm{C}\right)$. Fig. 9 demonstrates that the diagonal shrinkage of the fired specimens gradually increases with the increase in the addition of RHA in the compositions as well as with the increase of the firing temperature. However, an anomaly was observed, that is, the decrease in the shrinkage at addition higher than $50 \mathrm{~m} \%$ RHA (at $1150{ }^{\circ} \mathrm{C}$ ) and $45 \mathrm{~m} \%$ (at $1200^{\circ} \mathrm{C}$ ). On the other hand, the bulk density increases and porosity decreases with the increase in firing temperature and RHA content, except for the specimens $\mathrm{A}_{55}\left(\right.$ at $\left.1150^{\circ} \mathrm{C}\right)$ and $\mathrm{A}_{50}$ to $\mathrm{A}_{55}\left(\right.$ at $\left.1200^{\circ} \mathrm{C}\right)$; therein the bulk density decreases and porosity slightly increases, similarly to the shrinkage behavior (see Fig. 10). There are two conflicting approaches controlling the densification behavior. The first one is the decomposition and volatilization process occurring in the raw feed CKD and RHA during firing. This approach is accompanied by significant weight loss (see TG-DSC in Fig. 2) and contributes to the formation of more pores while the other one is the compact sinterability. The reduction in total porosity with the increase in any of the studied parameters suggests that the latter approach is more pronounced and significant [26]. The significant increase in shrinkage and bulk density (rapid densification) occurring upon the increase in RHA content in the compositions can be explained by the higher sinterability of the finer RHA particles [13] and their flabby

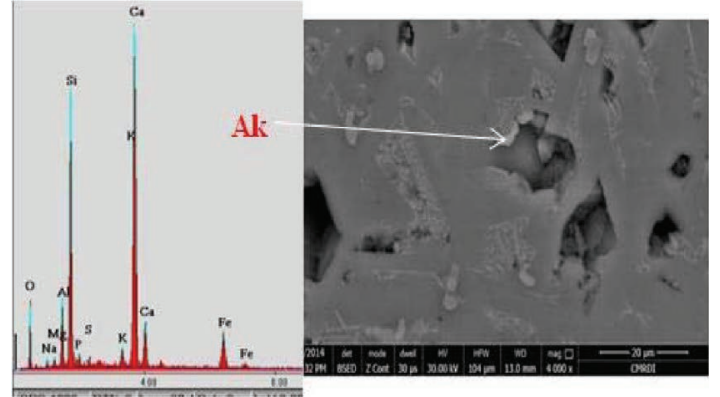

$A_{30}$

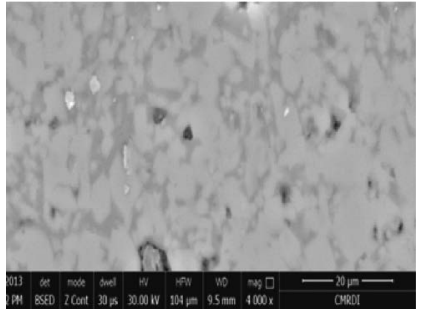

$A_{35}$

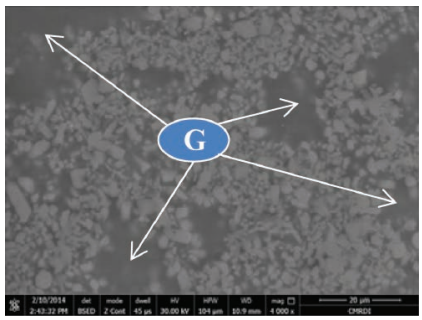

$A_{45}$

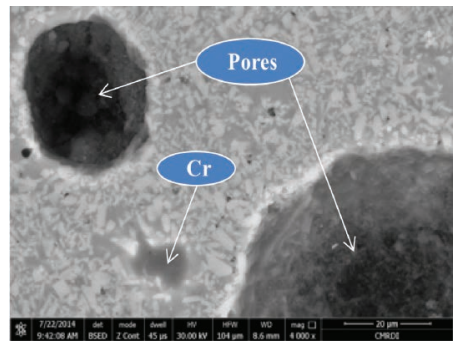

$A_{55}$

Fig. 8. Microstructure of all batches sintered for $2 \mathrm{hrs}$ at $1200^{\circ} \mathrm{C}$, Ak: akermanite, Cr: cristobalite, G: glass.

8. ábra A 2 órán át, $1200^{\circ} \mathrm{C}$ hömérsékleten szinterelt keverékek mikroszerkezete; Cr: krisztobalit, Ak: akermanit, G: üveg

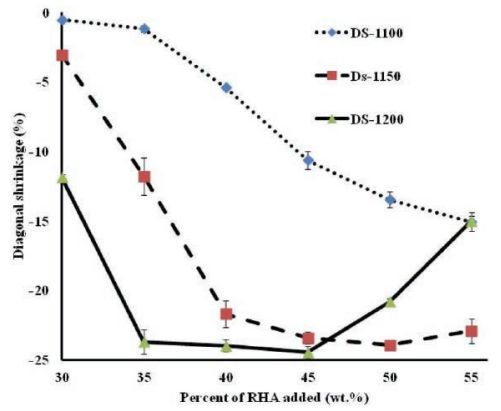

Fig. 9. Diagonal shrinkage of the cement kiln dust pellets containing variable content of RHA and fired at temperatures $1100-1200^{\circ} \mathrm{C}$, (DS: diagonal shrinkage)

9. ábra A különbözö RHA tartalommal cement kemenceporból $1100-1200^{\circ} \mathrm{C}$ hőmérsékleten szinterelt próbatestek átmérö irányú zsugorodása 
nature that is responsible for the high response of specimens to heat shrinkage [9]. Furthermore, it has been reported that the amount of liquid phase that governs the degree of densification varies with the nature of additives and its amount [60]. In this context, it was found that the addition of more amorphous rice husk ash (RHA) leads to the formation of more viscous glass flow that precipitates in the voids present through the whole specimen, which results in increasing its sinterability (see Figs. 6, 7 and 8). On the other hand, the high content of $\mathrm{CaO}$ in $\mathrm{CKD}$ (see Table 3) tends to increase the binary eutectic temperature of the mixture; it prefers to react with other ingredients in the mixure, forming new ceramic phases rather than entering into glassy phase. As a consequence, the specimens containing higher contents of CKD showed higher porosity and lower mass density as well as diagonal shrinkage than those containing lower CKD contents [61]. In addition, the increase in the sintering temperature leads to formation of more liquid phase of lower viscosity that in turns leads to the increase of the sinterability [13]. The enhancement in sinterability facilitates the grain boundaries to contact on the expense of the entire porosity leading to pore closing and elimination [26]. However, what happened on decreasing the densification of the specimens at a higher addition of RHA at $1150{ }^{\circ} \mathrm{C}$ and $1200^{\circ} \mathrm{C}$ indicated that the third effective parameter vigorously contributes to the sinterability. This parameter is expected to be the silica phase transformation that is noticed during XRD analysis of the fired specimens Figs. 4 and 5. These figures indicate that the excessive unreacted amorphous RHA in the anomalous samples is transformed into crystalline cristobalite that affects negatively the densification; crystalline phase has considerably higher viscosity than amorphous phase [13]. This can be explained to some extent by the decrease in the bulk density and the diagonal shrinkage in the specimens. Also, it has been found that the porosity of the specimens $A_{55}$ (at $1150{ }^{\circ} \mathrm{C}$ ) and $\mathrm{A}_{45}$ (at $1200^{\circ} \mathrm{C}$ ), dropped to zero and their bulk density attained maximum, $2.46 \mathrm{~g} / \mathrm{cm}^{3}$ and $2.45 \mathrm{~g} / \mathrm{cm}^{3}$, respectively. The increase in the addition of RHA in the compositions of such vitrified specimens leads to the formation of more glassy phase and in turns some gases can migrate through the matrix creating closed pores and bloating of the specimen. As a result, their bulk density and shrinkage decrease whilst their porosity increases.

\subsection{Mechanical tests}

\subsubsection{Compressive strength}

Fig. 11 shows the compressive strength for all the specimens containing various compositions $A_{30}$ to $A_{55}$ fired in the temperature range $1100-1200{ }^{\circ} \mathrm{C}$. The results show that the compressive strength increases with the increase in the firing temperature and RHA content. This is congruent with the bulk density and apparent porosity results. At $1150{ }^{\circ} \mathrm{C}$ and $1200^{\circ} \mathrm{C}$, the specimen $\mathrm{A}_{45}$ showed the maximum strength, $177 \mathrm{MPa}$ (at $1150^{\circ} \mathrm{C}$ ) and $353 \mathrm{MPa}$ (at $1200^{\circ} \mathrm{C}$ ), then, the strength decreased upon the further addition of RHA in this specimen till reaching $74 \mathrm{MPa}\left(\right.$ at $1150^{\circ} \mathrm{C}$ ) and $182 \mathrm{MPa}$ (at $1200^{\circ} \mathrm{C}$ ) for the specimen $\mathrm{A}_{55}$. The increase in the strength with the sintering temperature and the RHA content can be

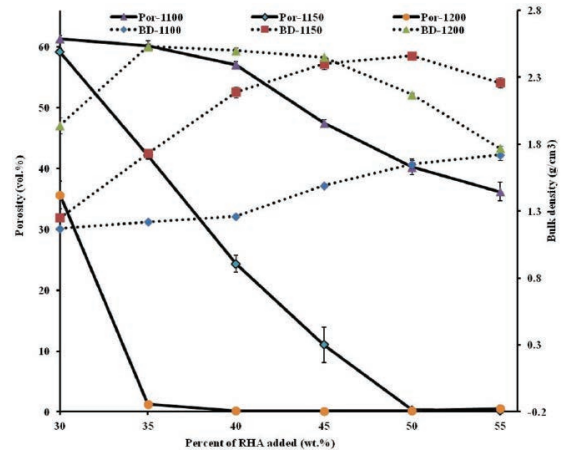

Fig. 10. Porosity and bulk density of the cement kiln dust pellets containing variable content of RHA and fired at temperatures $1100-1200^{\circ} \mathrm{C}$, (BD: bulk density, por: porosity)

10. ábra A különböző RHA tartalommal cement kemenceporból $1100-1200^{\circ} \mathrm{C}$ hömérsékleten szinterelt próbatestek porozitása és sürüsége

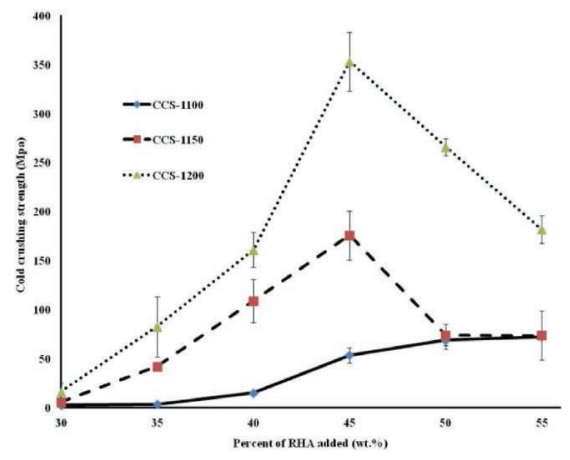

Fig. 11. Compressive strength of the cement kiln dust pellets containing variable content of RHA and fired at temperatures $1100-1200^{\circ} \mathrm{C}$ (CCS: Cold crushing strength)

11. ábra A különbözö RHA tartalommal cement kemenceporból $1100-1200^{\circ} \mathrm{C}$ hömérsékleten szinterelt próbatestek nyomószilárdsága

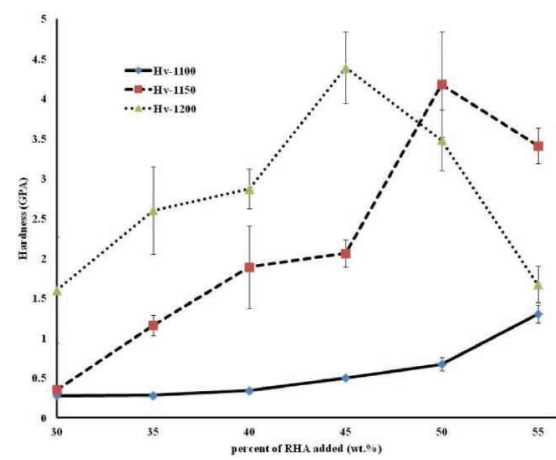

Fig. 12. Hardness of the cement kiln dust pellets containing variable content of RHA and fired at temperatures $1100-1200^{\circ} \mathrm{C}$ (Hv: hardness vickers)

12. ábra A különböző RHA tartalommal cement kemenceporból $1100-1200^{\circ} \mathrm{C}$ hömérsékleten szinterelt próbatestek Vickers keménysége

understood in view of increase of bulk density and decrease of porosity ensuing from sintering phenomena [62] through which particle rearrangement and liquid diffusion to pores takes place. This liquid cements the well developed crystals giving a good compaction and higher compressive strength [63]. The amount of liquid should be such that it just acts as bond between the grains [60]. Too much formation of glassy phase in $\mathrm{A}_{50}$ and $\mathrm{A}_{55}$ specimens fired above $1100^{\circ} \mathrm{C}$ and migration of gases therein caused internal stress and led to lowering their densification and increasing their brittleness and in turns their compressive strength is decreased $[9,63]$. 


\subsubsection{Vickers micro-hardness}

Vickers micro-hardness were found to increase with the increase of the firing temperature and the RHA content (see Fig. 12). This can be attributed to the surface vitrification and the formation of well-developed wollastonite crystals ( $\mathrm{Hv}$ 4.1-5.24 GPa) as well as the increase of density and decrease of porosity relevant to the sintering process. However, there was an anomaly, that is the fall in the hardness of the specimens containing RHA more than $50 \mathrm{~m} \%$ (at $1150{ }^{\circ} \mathrm{C}$ ) and $45 \mathrm{~m} \%$ (at $1200^{\circ} \mathrm{C}$ ), despite the formation of cristobalite that has higher hardness $\sim 9.62 \mathrm{GPa}$ in such specimens. This can be explained in terms of the surface softening [37] of such specimens due to formation of glassy phase vigorously, more than necessary, and migration of gases therein results in lowering their densification and in turns their surface hardness is decreased. Accordingly, the specimens $\mathrm{A}_{50}$ (at $1150^{\circ} \mathrm{C}$ ) and $\mathrm{A}_{45}$ (at $1200^{\circ} \mathrm{C}$ ) showed the maximum surface hardness $4.18 \mathrm{GPa}$ and $4.4 \mathrm{GPa}$, respectively.

\section{Concluding remarks}

1. Valuable and commercial wollastonite-based ceramics have been successfully synthesized from the most dangerous industrial and agricultural wastes (CKD and RHA) through reactive crystallization sintering at lower temperature $\left(1100-1200^{\circ} \mathrm{C}\right)$ compared to their synthesis from the pure constituents $\left(>1400^{\circ} \mathrm{C}\right)$.

2. No mineralizers have been added to CKD-RHA mixes, where the impurities present in CKD and RHA acted as sinter-improving oxides that formed glassy phase and induced the early vitrification of such mixes.

3. Utilization of the amorphous active RHA in place of crystalline quartz sand resulted in:
a) A reduction in the sintering temperature of the mixes of about $50^{\circ} \mathrm{C}$ to $100^{\circ} \mathrm{C}$ and this in turn gives rise to a considerable saving in time and heat energy leading to a significant economical production of wollastonite.
b) The increase in the strength of the fired specimens due to the increase of the amount of glassy phase in case of RHA addition. This glassy phase cements the well-developed crystals giving a good compaction and higher resistance to compression.

4. The measured densification and mechanical properties of the fired specimens was found to increase with the increase in firing temperature and RHA content. However, there was an anomaly that is the fall in these properties at higher addition of RHA (50-55 m\%) at $1150{ }^{\circ} \mathrm{C}-1200^{\circ} \mathrm{C}$. This was attributed to the formation of more glassy phase over the limit and migration of gases through this liquid creating closed pores and bloating of the specimen result in lowering their densification and mechanical properties.

\begin{tabular}{|c|c|c|c|c|c|c|}
\hline $\begin{array}{l}\text { Firing } \\
\text { Tempera- } \\
\text { ture }\end{array}$ & $\begin{array}{l}\text { Speci- } \\
\text { men } \\
\text { code }\end{array}$ & $\begin{array}{l}\text { Phases } \\
\text { Identified }\end{array}$ & $\begin{array}{l}\text { Distin- } \\
\text { guished } \\
\text { angles }\end{array}$ & & & $\begin{array}{l}\text { PDF } \\
\text { card }\end{array}$ \\
\hline & & & $2^{\circ} \theta$ & $2^{\circ} \theta$ & $2^{\circ} \theta$ & \\
\hline \multirow[t]{8}{*}{$1100^{\circ} \mathrm{C}$} & $\mathrm{A}_{30}$ & $\beta$-CS & 2.98 & 3.31 & 3.52 & 75-1396 \\
\hline & & Ak & 2.85 & 3.07 & 1.75 & $72-2127$ \\
\hline & $A_{35}$ & $\beta$-CS & & & & \\
\hline & $A_{40}$ & $\beta-C S$ & & & & \\
\hline & $A_{45}$ & $\beta-C S, S_{1}$ & & & & \\
\hline & $A_{50}$ & $\beta-C S, S_{1}$ & & & & \\
\hline & $A_{55}$ & $\beta$-CS, & & & & \\
\hline & & $\mathrm{S}_{1}$ & 4.08 & 2.49 & & $76-0937$ \\
\hline \multirow[t]{6}{*}{$1150^{\circ} \mathrm{C}$} & $\mathrm{A}_{30}$ & $\beta-C S, A k$ & & & & \\
\hline & $A_{35}$ & $\beta-C S$ & & & & \\
\hline & $A_{40}$ & $\beta-C S$ & & & & \\
\hline & $A_{45}$ & $\beta$-CS & & & & \\
\hline & $A_{50}$ & $\beta-C S$ & & & & \\
\hline & $A_{55}$ & $\beta-C S, S_{1}$ & & & & \\
\hline \multirow[t]{6}{*}{$1200^{\circ} \mathrm{C}$} & $A_{30}$ & a-CSS & 3.24 & 3.22 & 1.97 & $19-0248$ \\
\hline & $\mathrm{A}_{35}$ & $a-C S, \beta-C S$ & & & & \\
\hline & $A_{40}$ & $\beta$-CS & & & & \\
\hline & $\mathrm{A}_{45}$ & $\beta$-CS & & & & \\
\hline & $A_{50}$ & $\beta-C S$ & & & & \\
\hline & $A_{55}$ & $\beta-C S, S_{1}$ & & & & \\
\hline
\end{tabular}

$\mathrm{C}: \mathrm{CaO}, \mathrm{S}: \mathrm{SiO}_{2},\left(\mathrm{~S}_{1}\right.$ : Cristobalite, $\beta-\mathrm{CS}$ : wollastonite-2M, a-CS: Cyclowollastonite), Ak, Akermanite: $\left(\mathrm{Ca}_{1.53} \mathrm{Na}_{0.51}\right)\left(\mathrm{Mg}_{0.39} \mathrm{Al}_{0.41} \mathrm{Fe}_{0.16}\right)\left(\mathrm{Si}_{2} \mathrm{O}_{7}\right)$

Table 5. Crystalline phases identified in the fired specimens.

5. táblázat A szinterelt próbatestekben azonosított krisztallin fázisok

\section{References}

[1] Segadães, A. M.: Use of phase diagrams to guide ceramic production from wastes. Advances in applied ceramics 2006;105:54-46. http://dx.doi.org/10.1179/174329006X82927

[2] Savender, A.: Top 75 global cement companies. Global Cem Magazine., 9 (2013). http://www.globalcement.com/pdf/eGCDec13ns.pdf

[3] Askar, Y. - Jago, P. - Mourad, M. M. - Huisingh, D.: The cement industry in Egypt: Challenges and innovative cleaner production solutions. In: Production solutions knowledge Collaboration \& Learning for Sustainable Innovation ERSCP-EMSU conference, Delft, The Netherlands, October 2529, 2010.

[4] El-Mahllawy, M. S.: An investigation on the effect of cement kiln dust and glauconite on the properties of acid resisting brick. Int J Sci Tech 2013;2:43-30.

[5] El-Abssawy, A. A. - Hassanien, M. A. - Ibrahim, Y. H. - Abdel Latif, N. M.: Health risk assessment of workers exposed to heavy metals in cement kiln dust (CKD). J Am Sci 2011;7:316-308.

[6] Ewais, E. M. M. - Ahmed, Y. M. Z. - El-Amir, A. A. M. - El-Didamony, H.: Cement kiln dust-quartz derived wollastonite and its composites (Under Publication).

[7] Kumar, Ajay - Mohanta, Kalyani - Kumar, Devendra - Parkash, Om: Properties and industrial applications of rice husk: A review. International Journal of Emerging Technology and Advanced Engineering 2012;2:2250-2259.

[8] Koteswara Rao, D. - Pranav, P. R. T. - Anusha, M.: Stabilization of Expansive Soil With Rice Husk Ash, Lime and Gypsum - An Experimental Study. Int. J. Eng. Sci. Tech., 3, 8085-8076 (2011).

[9] Prasad, C. S. - Maiti, K. N. - Venugopal, R.: Effect of Rice Husk Ash in WhiteWare Compositions. Ceram. Int., 27, 635-629 (2001). http://dx.doi.org/10.1016/S0272-8842(01)00010-4

[10] Gidde, M. R. - Jivani, A. P.: Waste to Wealth - Potential of Rice Husk in India, a Literature Review. Proceedings of the international conference on cleaner technologies and environmental management PEC, Pondicherry, India, January 4-6, 2007, pp.586-590. 
[11] Rozainee, M. - Ngo, S. P. - Salema, A. A. - Tan, K. G. - Ariffin, M. Zainura, Z. N.: Effect of fluidising velocity on the combustion of rice husk in a bench-scale fluidised bed combustor for the production of amorphous rice husk ash. Bioresource Technology 99 (2008) 703-713. http://dx.doi.org/10.1016/j.biortech.2007.01.049

[12] Kapur, P. C.: Thermal Insulations From Rice Husk Ash, an Agricultural Waste. Ceramurgia Int., 6, 78-75, (1980). http://dx.doi.org/10.1016/0390-5519(80)90045-9

[13] Nayak, J. P. - Bera, J.: Effect of Sintering temperature on phase-formation behavior and mechanical properties of silica ceramics prepared from rice husk ash. Phase Transit., 82, 888-879 (2009). http://dx.doi.org/10.1080/01411590903471564

[14] Chandrasekhar, S. - Satyanarayana, K. G.- Pramada, P. N.- Raghavan, P.: Processing, properties and applications of reactive silica from rice husk-an overview, Review. Journal of materials science 2003;38:3159-3168. http://dx.doi.org/10.1023/A:1025157114800

[15] Ghani, W. A. W. A. K. - Abdullah, M. S. F. - Loung, C. J. - Ho, C. J. Matori, K. A.: Characterization of Vitrified Malaysian Agrowaste Ashes As Potential Recycling Material. Int. J. Eng. Tech., 6, 72-66 (2009).

[16] Zawrah, M. F. - Zayed, M. A. - Ali, M. R. K.: Synthesis and Characterization of $\mathrm{SiC}$ and $\mathrm{SiC} / \mathrm{Si} 3 \mathrm{~N} 4$ Composite Nano Powders from Waste Material. J. Hazard. Mater., 227-228, 256-250 (2012). http://dx.doi.org/10.1016/j.jhazmat.2012.05.048

[17] Niyomwas, S.: Synthesis and Characterization of Silicon-Silican Carbide Composites from Rice Husk Ash via Self-Propagating High Temperature Synthesis. J. Met. Mat. Min., 19, 25-21 (2009).

[18] Pavarajarn, V. - Precharyutasin, R. - Praserthdam, P.: Synthesis of Silicon Nitride Fibers by the Carbothermal Reduction and Nitridation of Rice Husk Ash. J. Am. Ceram. Soc., 93, 979-973 (2010). http://dx.doi.org/10.1111/j.1551-2916.2009.03530.x

[19] Onojah - Amah, A. N. - Ayomanor, B. O.: Comparative Studies of Silicon from Rice Husk Ash and Natural Quartz. Am. J. SCI. Ind. Res., 3, 149-146 (2012).

[20] Acharya, H. N. - Dutta, S. K.: Production of Magnesium Silicide and Silane from Rice Husk Ash. Sol. Energ. Mater., 3, 445-441 (1980). http://dx.doi.org/10.1016/0165-1633(80)90032-5

[21] Ahmed, K. - Nizami, S. S. - Raza, N. Z. - Kamaluddin, S. - Mahmood, K. An Assessment of Rice Husk Ash Modified, Marble Sludge Loaded Natural Rubber Hybrid Composites. J. Mater. Environ. Sci., 4, 216-205 (2013).

[22] Chiang, K. Y. - Chou, P. H. - Hua, C. R. - Chien, K. L. - Cheeseman, C.: Lightweight Bricks Manufctured from Water Treatment Sludge and Rice Husks. J. Hazard. Mater., 171, 82-76 (2009). http://dx.doi.org/10.1016/j.jhazmat.2009.05.144

[23] Ugheoke, I. - Mamat, O. - Wahjoedi, B. A.: Optimization of Production Process Parameters of Rice Husk Silica (RHS) Refractories. J. Aust. Ceram. Soc., 49, 100-92 (2013).

[24] Ismail, H. - Shamsudin, R. - Abdul Hamid, M. A. - Jalar, A.: Synthesis and Characterization of Nano-Wollastonite from Rice Husk Ash and Limestone. Mater. Sci. forum., 756, 47-43 (2013) http://dx.doi.org/10.4028/www.scientific.net/MSF.756.43

[25] Yu, Q. - Sawayama, K. - Sugita, S. - Shoya, M. - Isojima, Y.: The Reaction Between Rice Husk Ash and $\mathrm{Ca}(\mathrm{OH})_{2}$ Solution and the Nature of Its Product. Cem. Concr. Res., 29, 43-37 (1999). http://dx.doi.org/10.1016/S0008-8846(98)00172-0

[26] Ahmed, Y. M. Z. - Ewais, E. M. - Zaki, Z. I.: Production of porous silica by the combustion of rice husk ash for tundish lining. J Univ Sci Technol B 15(2008) 307-313. http://dx.doi.org/10.1016/S1005-8850(08)60058-4

[27] Khater, G. A.: Glass-Ceramics in the $\mathrm{CaO}-\mathrm{MgO}-\mathrm{Al}_{2} \mathrm{O}_{3}-\mathrm{SiO}_{2}$ System based on Industrial Waste Materials. J. Non-Cryst. Solids, 356, 3070-3066 (2010). http://dx.doi.org/10.1016/j.jnoncrysol.2010.02.030

[28] Harabi, A. - Chehlatt, S.: Preparation process of a highly resistant wollastonite bioceramics using local raw materials. J Therm Anal Calorim 2013;111:203-211. http://dx.doi.org/10.1007/s10973-012-2242-5

[29] Nour, W. M. N. - Mostafa, A. A. - Ibrahim, D. M.: Recycled wastes as precursor for synthesizing wollastonite. Ceram Int 2008;34:105-101. http://dx.doi.org/10.1016/j.ceramint.2006.08.019
[30] Nour, W. M. N. - Mostafa, A. A. - Koch, D. 2 Grathwohl. G.: Porous ceramics based on synthetic wollastonite. Interceram 2007;56: 428-424.

[31] Volochko, A. T. - Podbolotov, K. B. - Zhukova, A. A.: Preparation of porous ceramic materials based on wollastonite using silicon-containing components. Refract Ind Ceram 2011;52:29-24.

http://dx.doi.org/10.1007/s11148-011-9393-y

[32] Nizami, M. S.: Studies on synthesis of wollastonite from rice husk ash and limestone. Ph.D, university of the Punjab in Pakistan. 1993.

[33] Wang, H. - Zhang, Q. - Yang, H. - Sun, H.: Synthesis and microwave dielectric properties of $\mathrm{CaSiO}_{3}$ nanopowder by the sol-gel process. Ceram Int 2008;34:1408-1405.

http://dx.doi.org/10.1016/j.ceramint.2007.05.001

[34] Pei, L. Z. - Yang, L. J. - Yang, Y. - Fan, C. G. - Yin, W. Y. - Chen, J.: A green and facile route to synthesize calcium silicate nanowires. Mater Charact 2010;61:1285-1281.

http://dx.doi.org/10.1016/j.matchar.2010.07.002

[35] Grigoryan, G. O. - Arutyunyan, G. A. - Grigoryan, K. G. - Khachatryan A. A.: Synthesis of wollastonite from the carbonate-containing gaize of Lithuania. Theor Found Chem Eng 2010;44:478-476. http://dx.doi.org/10.1134/S0040579510040196

[36] Lin, K. - Chang, J. - Lu, J.: Synthesis of wollastonite nanowires via hydrothermal microemulsion methods. Mater Lett 2006;60:3010-3007. http://dx.doi.org/10.1016/j.matlet.2006.02.034

[37] Kumagai, S. - Sasaki, J.: Carbon/Silica Composite Fabricated from Rice Husk by Means of Binderless Hot-Pressing. Bioresour. Technol., 100, 33153308, (2009)

[38] Circulation phenomena in the clinkerization process, Cement seminar process technology, Holderbank.

http://222.255.19.250/Picture/PRJ-MEC/VAN/Holcim/Circulation\%20 Phenomena\%20in\%20the\%20Clinkerization\%20Process.pdf

[39] AbdEl-Fattah, W. I. - El-Didamony, H.: Thermal investigation on electrostatic precipitator kiln dust, Thermochim Acta 51(1981) 297-306 http://dx.doi.org/10.1016/0040-6031(81)85167-2

[40] Nielsen, A. R. - Larsen, M. B. - Glarborg, P. - Johansen, K. D.: Hightemperature release of SO2 from calcined cement raw materials, Energ Fuel 25(2011) 2917-2926. http://dx.doi.org/10.1021/ef2006222

[41] Glasser, F. P.: The formation and thermal stability of spurrite, $\mathrm{Ca}_{5}\left(\mathrm{SiO}_{4}\right)_{2} \mathrm{CO}_{3}$, Cem Concr Res 3 (1973) 23-28. http://dx.doi.org/10.1016/0008-8846(73)90058-6

[42] Huntzinger, D. N.: Carbon dioxide sequestration in cement kiln dust through mineral carbonation, Doctor of philosophy, Michigan Technological University, 2006.

http://services.lib.mtu.edu/etd/DISS/2006/Geological\&MiningEng\&Sci/ huntzingerd/diss.pdf

[43] El-Didamony, H. - Amer, A. A. - Helmy, I. M. - Mostafa, K.: Durability of sulphate resisting slag blended cements and mortars in ea water. Indian J. Eng. Mater. Sci 3(1996) 35-40.

[44] Klassen, V. K. - Ermolenko, E. P. - Michin, D. A. - Novosyolov, A. G.: Problem of impurity of salts of alkali metals in cement raw materials, Middle East J Sci Res 17(2013) 1130-1137.

http://dx.doi.org/10.5829/idosi.mejsr.2013.17.08.7087

[45] Armatys, K. A.: Thermochemical characterisation of the gas circulation in the relevant cement industry processes, Ph.D, Clausthal university of technology in Germany. 2011.

[46] Hofman, H. O. - Mostowitsch, W. : The behavior of calcium sulfate at elevated temperatures with some fluxes, T. Am. I. Min. Met. Eng. 39( 1909) 653-628.

[47] Perraki, M. - Perraki, T. - Kolovos, K. - Tsivilis, S. - Kakali, G.: Secondary raw materials in cement industry, J. Therm. Anal. Calorim.70(2002) 150-143. http://dx.doi.org/10.1023/A:1020609801903

[48] Flörke, O. W., Ber. Dtsch. Keram. Ges. 1959;38:89. http://nptel.ac.in/courses/113104059/lecture_pdf/Lecture\%204.pdf

[49] Make, I.: Mechanism of glass formation in Portland cement clinker. Cem Concr Res 9(1979) 757-763.

http://dx.doi.org/10.1016/0008-8846(79)90071-1 
[50] El-Mahllawy, M. S. - El-Sokkary, T. M.: Recycling of cement kiln dust and water glass sludge in the manufacture of acid resistant masonry units, HBRC J. 2(2006) 35-23.

[51] Jacob, C. J.: Synthesis of wollastonite from natural materials without fusion, united states Patent, 1976.

[52] ElBatal, H. A. - Ghoneim, N. A. - Ouis, M. A.: Preparation and characterization of glass and glass-ceramics from industrial waste materials including iron slag and cement dust.

http://www.iccm-central.org/Proceedings/ICCM17proceedings/Themes/ Industry/ADV\%20COMP\%20MATS\%20IN\%20CONSTRUCTION/ INT\%20-\%20ADV\%20COMP\%20MATS\%20IN\%20CONSTR/IA1.2\%20 Ouis.pdf

[53] Edgar, A. D.: Chemistry, occurrence and paragenesis of feldspathoids: A review. In: w. L. Brown, editor, Feldspars and Feldspathoids, Canada: Springer 137(1984) 501-532.

[54] Lloyd, F. E.: Experimental melting and crystallization of glassy olivine melilitites, Contrib Mineral Petrol 90(1985) 236-243. http://dx.doi.org/10.1007/BF00378264

[55] Capitaanio, F. - Larocca, F. - Improta, S.: High-temperature rapid pyrometamorphism induced by a charcoal pit burning, Int J Earth Sci 93(2004) 107-118.

http://dx.doi.org/10.1007/s00531-003-0374-3

[56] Kacim, S. - Hajjaji, M.: Firing transformations of a carbonatic clay from the high-atlas, Morocco, Clay Miner 38(2003) 361-365. http://dx.doi.org/10.1180/0009855033830102

[57] Kuo, Y. M. - Wang, J. W. - Wang, C. T. - Tsai, C. H.: Effect of water quenching and $\mathrm{SiO}_{2}$ addition during vitrification of fly ash Part 1: On the crystalline characteristics of slags, J Hazard Mater 152(2008) 994-1001. http://dx.doi.org/10.1016/j.jhazmat.2007.07.081

[58] Rashad, A. M. - Khalil, M. H.: A preliminary study of alkali-activated slag blended with silica fume under the effect of thermal loads and thermal shock cycles, Constr Build Mater 40(2013) 522-532. http://dx.doi.org/10.1016/j.conbuildmat.2012.10.014

[59] Chand, T. K. D. N. - Rohatgi, P. K.: Effect of Glass, Rice-Husk Ash and Wollastonite on Transverse Strength of Porcelain. J. Mater. Sci. Lett., 6, 280-277 (1987).

http://dx.doi.org/10.1007/BF01729324

[60] Osman, R. M. - Abu-El-Naga, H. - El-Alfi, E. A.: Influence of cement dust on ceramic properties of basalt bricks, Res J Pharm Biol Chem Sci 4(2013) 1494-1500.

[61] Nayak, J. P. - Bera., J.: Effect of sintering temperature on mechanical behaviour and bioactivity of sol-gel synthesized bioglass-ceramics using rice husk ash as a silica source. Appl. Surf. Sci., 257, 458-462(2010). http://dx.doi.org/10.1016/j.apsusc.2010.07.011
[62] Darweesh, H. H. M. - Wahsh, M. M. S. - Negim, E. M.: Densification and thermomechanical properties of conventional ceramic composites containing two different industrial byproducts, Am. Eurasian. J. Sci. Res.7(2012) 130-123.

http://dx.doi.org/10.5829/idosi.aejsr.2012.7.3.1104

\section{$\underline{\text { Ref.: }}$}

Ewais, Emad M. M. - Ahmed, Yasser M. Z. - El-Amir, Ahmed A. M. - El-Didamony, Hamdy: Cement kiln dust/rice husk ash as a low temperature route for wollastonite processing Építőanyag - Journal of Silicate Based and Composite Materials, Vol. 66, No. 3 (2014), 69-80. p. http://dx.doi.org/10.14382/epitoanyag-jsbcm.2014.14

Wollastonit szintézis alacsony hőmérsékleten cement kemencehamu és rizshéj hamu felhasználásával Veszélyes ipari hulladék (cement kemencehamu, CKD) és veszélyes mezôgazdasági hulladék (rizshéj hamu, RHA) alapanyagok felhasználásával szintetizált, környezetbarát, értékes wollastinit kerámiák tulajdonságait mutatja be a cikk. A vizsgált keverékeken a különbözô CKD és RHA adagolás hatását tanulmányozhatjuk. A nedves keveréssel homogenizált, szárított, átszitált keverékek szinterezési hômérséklete $1100-1200^{\circ} \mathrm{C}$ volt. A cikk bemutatja a fázisösszetételi, mikroszerkezeti, termogravimetriai, röntgendiffraktometriai és szilárdsági vizsgálatok eredményeit. Az eredmények igazolják, hogy már $1100^{\circ} \mathrm{C}$ hômérsékleten is sikeresen szinterelhetố wollastonit kerámia, kiegészítô adalékok nélkül is. Az eredmények rámutatnak, hogy jelentôs idô és energia megtakarítás érhetố el, ha az amorf struktúrájú RHA alapanyagot használják fel a kristályos szerkezetú módosulatok helyett. A kedvezô viselkedés oka az amorf struktúrájú RHA nagy fajlagos felülete és jelentôs reakcióképessége. A kutatási eredmények jó példát szolgáltatnak arra, hogy hogyan lehet veszélyes ipari és mezōgazdasági hulladékok felhasználásával értékes terméket előállítani. A kifejlesztett wollastonit kerámiák számos területen sikeresen felhasználhatók, jelentôs gazdasági elônyt eredményezve.

Kulcsszavak: cement kemencehamu (CKD), rizshéj hamu (RHA), keverék összetétel, szinterezés, wollastonit, mikroszerkezet, fázisösszetétel, tömörödés, mechanikai jellemzők

\section{Global Slag Conference and Exhibition 2014} Improving slag performance - New applications for slag - Global slag markets and trading

\section{Innovation, developments and networking To recovery and beyond}

\section{Who should come to this conference?}

Slag producers - slag users - cement producers - cement users - equipment vendors - traders and shippers - academics and researchers

The $10^{\text {th }}$ Global Slag Conference and Exhibition will take place at the Pullman Aachen Quellenhof on 8-9 December 2014.

\section{Conference topics}

- Slag and slag cement market trends · Slag product trends - Beneficiation of slag and slag products - Slag cement production and use · Case studies · New applications for slag and slag products

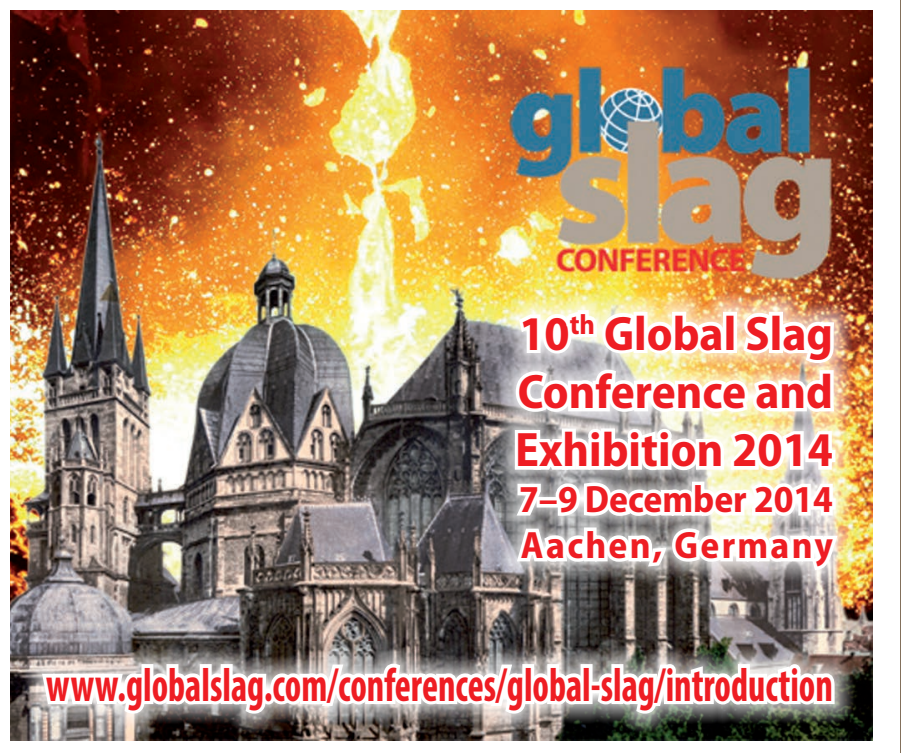

